DOI: 10.1515/pof-2015-0009

VOLUME 7, ISSUE 2, 2015

ISSN: $2036-5438$

\title{
Belgian Federalism after the Sixth State Reform
}

by

Jurgen Goossens and Pieter Cannoot*

Perspectives on Federalism, Vol. 7, issue 2, 2015 


\section{Abstract}

This paper highlights the most important institutional evolutions of Belgian federalism stemming from the implementation of the sixth state reform (2012-2014). This reform inter alia included a transfer of powers worth 20 billion euros from the federal level to the level of the federated states, a profound reform of the Senate, and a substantial increase in fiscal autonomy for the regions. This contribution critically analyses the current state of Belgian federalism. Although the sixth state reform realized important and long-awaited changes, further evolutions are to be expected. Since the Belgian state model has reached its limits with regard to complexity and creativity, politicians and academics should begin to reflect on the seventh state reform with the aim of increasing the transparency of the current Belgian institutional labyrinth.

Key-words

Belgium, state reform, Senate, constitutional amendment procedure, fiscal autonomy, distribution of powers, Copernican revolution 


\section{Introduction}

After the federal elections of 2010, Belgian politicians negotiated for 541 days in order to form the government of Prime Minister Di Rupo, which took the oath on 6 December 2011. This resulted in the (unofficial) world record of longest government formation period. After the Flemish liberal party (Open VLD) elicited the end of the government of Prime Minister Leterme, Belgian citizens had to vote on 13 June 2010. The right-wing nationalist party (N-VA) convincingly won the elections in Dutch-speaking Flanders, while the Socialist party (PS) acquired the most votes in French-speaking Wallonia. Negotiations of nearly a year and a half finally resulted into the so-called Butterfly Agreement on the sixth state reform of 11 October 2011. 'This reform inter alia included a transfer of powers worth 20 billion euros from the federal level to the level of the federated states (i.e. the regions and communities), a profound reform of the Senate, and a substantial increase in fiscal autonomy for the regions. The agreement was converted into legislation during the years 2012 to 2014 and is currently being implemented at the level of the states. Therefore, it is time to take a closer look at the current state of Belgian federalism after the sixth state reform and to reflect on its future.

In this regard, the following topics will be analysed: the 'trick' with the constitutional amendment procedure in article 195 of the Constitution (1.); the historical split of the electoral and judicial district Brussels-Halle-Vilvoorde (2.); the reform of the Senate (3.); the modification of the Special Finance Act, including the substantial increase in fiscal autonomy for the regions (4.); the distribution of powers between the federal level, the regions and communities (5.); the future of Brussels (6.) and finally the future of Belgian federalism (7.).

\section{Amendment of article 195 of the Constitution}

The implementation of the sixth state reform (2012-2014) through several constitutional amendments shows that the constitutional amendment procedure is at odds with the current Belgian federal cooperation model (Popelier 2012: 442). In order to implement the Butterfly Agreement on the sixth state reform, Parliament temporarily altered 
the constitutional amendment procedure itself in article 195 of the Constitution by adding a divergent 'transitional provision' to the amendment procedure, which provoked substantial criticism.

Article 195 of the Constitution prescribes the constitutional amendment procedure, which contains three phases. Firstly, Parliament (i.e. the Chamber of Representatives and the Senate) and the King each adopt a list of constitutional provisions which are 'declared to be revisable'. After approval of this list the dissolution of Parliament automatically follows, with the organisation of new elections within 40 days. Afterwards, the newly elected Parliament has the power to (only) amend those constitutional provisions which were declared to be susceptible to revision by Parliament and the King in their joint list. In order to amend the constitution, two thirds of the members of each Chamber of Parliament are required to be present, and two thirds of the members present must approve the amendment.

The procedure of article 195 dates back to the first Belgian constitution of 1831. At that time, there were legitimate reasons for its rigidity; it was the main aim of article 195 to avoid the possibility that an accidental majority could substantially amend the constitution without prior consultation of the voters.

In 2011, the list of constitutional provisions which were designated to be susceptible to revision did not contain all articles required for the implementation of the agreement on the sixth state reform. However, after a regime crisis of 541 days politicians wanted to avoid the organization of new elections. As a result, the negotiators of the sixth state reform used their legal toolbox in order to implement the entire agreement without the approval of a new revision statement and without new elections. The list included article 195 of the Constitution, namely the constitutional amendment procedure itself. Consequently, the negotiators decided to add a 'transitional provision' to article 195, which was only valid during the same legislative term and gave authority to immediately revise the necessary constitutional provisions. From a strictly legal perspective, one could argue that a two-thirds majority was permitted to amend article 195 in this way, even though the constitutional amendment procedure and its guarantees were in practice temporarily set aside.

The transitional provision contained an exhaustive list of constitutional provisions susceptible to immediate revision. An amendment could only be adopted with a two-thirds 
majority as required by article 195 and was not seen as a revision statement leading to dissolution of Parliament.

\subsection{Guarantees of article 195}

It has already been argued on a regular basis that the amendment procedure in article 195 of the Constitution is too rigid (Van Nieuwenhove 2012: 156). Legal scholars have questioned whether the aims of this procedure outweigh its adverse effects.

In theory, the Constituent Assembly aimed to ensure that the voters could express their opinion in an election about the constitutional provisions susceptible to revision. In practice, however, Parliament uses, or indeed abuses, the approval of a revision statement as the standard procedure to rescind parliament and hold new elections. Afterwards, the election campaign is often dominated by general policy issues instead of a thorough debate about the revision statement.

It was the intention of article 195 to avoid a rash approval of constitutional amendments, as the Constitution guarantees the fundamental basic principles which are essential to the rule of law. Consequently, it should not be possible to amend a constitution through the regular legislative procedure. A more rigid procedure ought to safeguard the fundamental character of the Constitution, which is obviously more than 'a scrap of paper'.

\subsection{Criticism}

The opposition parties heavily criticized the 'trick' with article 195 of the Constitution described above, as it dodged the guarantees of the amendment procedure. The Flemish right-wing nationalist party $(\mathrm{N}-\mathrm{VA})$ inter alia referred to article 187 of the Constitution, which forbids a partial or entire suspension of the Constitution. They argued that the transitional provision did not regulate the transition from an old to a new arrangement, but in fact constituted a temporary suspension of the Constitution (Vandernoot 2013). From the beginning of the consecutive legislative term, the ordinary amendment procedure would, once more, become the applicable law. Nevertheless, it is remarkable that N-VA itself, when the party was still involved in the negotiations, also launched several proposals which required the amendment of articles over and above those susceptible to revision. It seems highly unlikely that N-VA would have proposed to wait another legislative term 
rather than take advantage of some constitutional high-tech; the duty of the opposition is, of course, to oppose.

Moreover, N-VA petitioned the Venice Commission of the Council of Europe to scrutinize the temporary revision of article 195 of the Constitution. ${ }^{\text {III }}$ The Commission argued that the amendment procedure ought to safeguard some important guarantees, but at the same time stated that in practice these aims have not always been fully accomplished. As a result, the Venice Commission refuted the arguments of the opposition regarding the guarantees of article 195. Furthermore, the Commission decided that article 195 of the Constitution had not been suspended though indeed it had been altered. On 20 June 2012, the Venice Commission thus ruled that the 'transitional provision' neither violated the letter and the spirit of the Constitution nor international norms and standards. ${ }^{\text {IV }}$

\subsection{Towards a reform of article 195?}

Although the Venice Commission ruled that the transitional provision was not unconstitutional, the 'trick' can still be criticised. Indeed, the adoption of the 'transitional provision' could be used as a precedent, so that in the future only one article, namely article 195 of the Constitution, might be declared susceptible to amendment. Such an evolution would of course blatantly undermine the guarantees provided by article 195 .

The initiation of a debate about a sustainable reform of article 195 is recommendable, as the efficacy of the current procedural guarantees is highly questionable. We believe that it is time to thoroughly modernise the constitutional amendment procedure, and adapt it to the current federal cooperation model, instead of relying on the 'trick' with article 195 for possible future state reform. Some politicians are reluctant to discuss such reforms, as they fear that a simplification of the amendment procedure would make further devolution to the regions and communities easier and would thus contribute to the dismantlement of the federal level.

Despite an explicit demand of N-VA, in view of facilitating its institutional reformist agenda after the next election, the intention to include article 195 in the revision statement at the end of the current legislative term has not been mentioned in the coalition agreement of the new government of Prime Minister Michel. Undoubtedly, this important debate will be revived at the end of the current legislative session. 


\section{The split of Brussels-Halle-Vilvoorde}

The electoral district of Brussels-Halle-Vilvoorde (BHV) dates back to 1830, the year in which Belgium became independent. Ever since the state reforms after 1970 which gave rise to the regions and communities, the electoral district BHV has been a constant source of friction in Belgian politics. In 2002, while an amendment of the federal Election Act merged the majority of the former electoral constituencies based on communal districts into provincial electoral districts, in Flemish-Brabant the existing electoral districts BHV and Leuven remained unchanged. The BHV district spanned two regions (and two language areas), namely the Flemish Region and the bilingual Brussels-Capital Region. It included the 19 municipalities of the bilingual Brussels-Capital Region as well as 35 municipalities of the province Flemish-Brabant.

Most of the Flemish parties, however, considered BHV as a mechanism supporting the 'Frenchification' of the Flemish areas adjacent to Brussels. In federal and European elections, French-speaking politicians from Brussels could win votes in the 35 Flemish municipalities of Flemish-Brabant. The Flemish politicians, in their turn, also benefited from the BHV district to get better electoral results in Brussels. Nevertheless, BHV became a symbol of the anomalies and antagonisms in Belgian federalism.

In 2003, the Belgian Constitutional Court ruled that, in view of the new provincial electoral districts, maintaining the old communal districts Leuven and BHV constituted an unacceptable inequality. ${ }^{\mathrm{V}}$ The Court gave the legislature four years to resolve the 'BHVproblem' (Peeters and Mosselmans 2009: 5). Despite the Court's decision, the BHV case dominated Belgian politics for a period far exceeding these four years and resulted in the fall of the Leterme-II government in 2010. It was apparent that a compromise on BHV had to be reached before a new government could be formed.

On 14 September 2011, more than eight years after the landmark decision of the Constitutional Court, an agreement was reached on the split of the BHV electoral district. The agreement was implemented by Chapter 2 of the Act of 19 July 2012 amending the federal Election Act. The province of Flemish-Brabant became a separate provincial electoral district. The district includes the former communal districts of Halle-Vilvoorde and Leuven. In addition, the Brussels-Capital electoral district was created. As a compensation for the Flemish demand to split BHV, the Act grants French-speaking 
citizens 'special modalities' in the six suburban municipalities with facilities ${ }^{\mathrm{VI}}$ surrounding Brussels.

These 'special modalities' guarantee a status quo for the acquired rights of the Frenchspeaking citizens living in these six municipalities. They retain the choice to vote for political candidates of the Flemish-Brabant district or for those of Brussels Capital. In other words, these voters retain the right to vote for candidates in Brussels, even though they are taken into account to calculate the number of parliamentary seats accorded to Flemish-Brabant. This special regime is entrenched in article 16bis of the Special Act on Institutional Reform. As a result, an alteration of this regime requires in each parliamentary Chamber a majority of the votes cast both in the Flemish and the French language group as well as an overall two-thirds majority of the votes cast in each Chamber.

The institutional opposition did not agree with this solution for BHV. Several Frenchspeaking parties criticised the loss of the right of the inhabitants of the remaining 29 municipalities of Halle-Vilvoorde to vote for candidates from Brussels. They regarded the compensatory measures to be inadequate. On the other side, according to the Flemish opposition parties too many concessions were made to obtain the split. The main criticisms related to the practical consequences of the split for Flemish-Brussels representation in the Chamber of Representatives. A Fleming elected in the district of Brussels Capital would become a rarity, as it would in practice only be possible if almost all Flemish parties were to come together to constitute one electoral list. This Flemish fear indeed came true in 2014, because in the recent federal election only French-speaking politicians were elected in Brussels Capital.

\subsection{Special dispute settlement in the suburban municipalities of Brussels}

Disputes between the communities, mostly concerning the correct interpretation of the Belgian language legislation, regularly arise in the six municipalities with facilities in the suburban area of Brussels. Consequently, the sixth state reform provided a legal solution to address these problems. From now on, all administrative disputes originating in these six municipalities could be settled by the General Assembly of the Council of State (Baeckeland and Nelissen 2014: 258; Velaers 2014a: 172). This assembly now also has the final word on disputes concerning the appointment of mayors in these six municipalities (Remiche and Van den Eynde 2013). The General Assembly has a bilingual French-Dutch composition 
which seemed advisable for cases concerning delicate language issues. On the other hand, the assembly now also has jurisdiction over disputes which are not at all related to tensions between the Flemish and French Communities, such as the annulment of a planning permission for building a henhouse. This 'legal overkill' has rightly been criticised by the Flemish institutional opposition.

In the meantime, the General Assembly of the Council of State has ruled for the first time on a dispute about the interpretation of the above-mentioned language facilities. ${ }^{\text {VII }} \mathrm{On}$ the one hand, the Council of State acknowledges the primacy of the Dutch language in the six Flemish suburban municipalities. On the other hand, it points out that the administrative requirement demanded by the Flemish Government to express one's language preference every single time violates the minority rights of the French-speaking citizens. Hence, the Council of State concludes that a request for language facilities only has to be renewed every four years.

\subsection{Reform of the BHV judicial district}

The agreement on the sixth state reform not only included the split of the BHV electoral district and the special regime for the municipalities with facilities, but also provided a reform of the BHV judicial district (Gosselin 2013). This judicial district was difficult to manage due to its complex structure. The Act of 19 July 2012 on the reform of the judicial district of Brussels implemented a thorough reform. The Act split the former prosecutor's office into a prosecutor's office of Halle-Vilvoorde and a prosecutor's office of Brussels. As a result, the prosecutor's offices are able to decide on their own policy, taking into account the specific criminal activities most frequently occurring in their district. However, the courts themselves were not territorially divided. They are duplicated based on language; every court is now divided into two monolingual sections. Consequently, there is no real split of the BHV judicial district (Vandenbruwaene 2014: 207; Vanlerberghe 2014: 202). With some minor exceptions, this Act has recently passed constitutional review. ${ }^{\text {VIII }}$

Generally, we can conclude that the negotiations on the split of Brussels-HalleVilvoorde were conducted in a typical Belgian way. In order to reach an agreement on the sixth state reform, both Flemings and Walloons made concessions. As BHV afflicted 
Belgium for almost fifty years and led to an institutional crisis, it is important that an agreement has finally been reached.

\section{Reform of the Senate}

The Belgian Senate looks completely different after the sixth state reform. A thorough reform of the bicameral system has been implemented, whereby the composition and legislative powers of the Senate were revised. From now on, the Senate is an assembly primarily representing the interests of the federated entities on the federal level, which fills a gap in the Belgian federal state structure. It is appropriate in a federal state that the federated entities have a say in (federal) matters which concern them (Goossens and Cannoot 2013: 6). Representation of the interests of federated entities principally - though not always - takes place within a second federal chamber (Popelier 2014: 57). Patricia Popelier theoretically distinguishes four sets of powers that can be distributed to the second chamber: (1) powers that directly relate to the federal state structure and functioning of the federated entities, (2) powers that influence the policy discretion of the federated entities, such as concurring powers, (3) powers that indirectly influence the discretion of the federated entities and (4) powers that do not relate to the federated entities (Popelier 2014: 59). Moreover, it is only if a second chamber is composed of a delegation from the Parliaments of the federated entities, that it should be expected to play a significant parliamentary role at the federal level (Popelier 2014: 58). After the reform, it is now up to the Senate to fulfil its new role as chamber of the federated entities.

\subsection{New composition}

The new Senate has become smaller (Fornoville 2014: 28): it now consists of 60 senators instead of 71. There are no longer directly elected senators; in the new Senate, 50 out of the 60 seats are occupied by senators who are appointed by and from the Parliaments of the communities and regions. Among these senators, the distribution of seats is based on the electoral results in the communities and regions. Before the sixth state reform, the Senate already had 21 so-called 'community senators', designated by and from the Parliaments of the communities. Although in this way the communities were represented at the federal level, the seats of the community senators were distributed based on the 
election results for the federal Senate and there were no representatives of the regions.

The other ten senators are 'co-opted senators'. The technique of co-optation was initially introduced to involve experts (technocrats) in the parliamentary work of the Senate. They were presumed to improve the quality of the debate and the legislation. Unfortunately, nowadays this category of senators is primarily used to provide a seat for politicians who could not be directly elected. Parliament preserved co-optation in the sixth state reform as a compensation for the split of the Brussels-Halle-Vilvoorde electoral district in order to ensure that (Flemish) Brussels politicians could still become members of the Senate.

Maintaining the technique of co-optation is a stain on the character of the reform (Muylle 2014: 114). The distribution of the ten seats is based on the election results of the Chamber of Representatives, which is inconsistent with the idea of the Senate as a chamber of the federated entities. Given the considerable reduction of legislative powers of the Senate, it would have been more rational to have given these co-opted politicians a seat in the Chamber instead. Either way, we believe that co-optation should be abolished since non-elected technocrats already work in the cabinets and as parliamentary staff members. Moreover, if experts want to become a Member of Parliament, they should participate in the elections.

\subsection{Vast reduction of powers}

The sixth state reform curtailed the powers of the Senate and transformed the institution into a non-permanent body which now holds a plenary meeting eight times per year. The unicameral procedure, in which the legislative power is vested in the Chamber of Representatives and the King without involvement of the Senate, became the standard legislative procedure. The unicameral procedure applies to all matters for which the optional or full bicameral procedure has not explicitly been prescribed by the Constitution. As a compensation, a second reading has been introduced in the Chamber of Representatives. As a result, the Senate will have substantially less legislative work.

The remaining powers of the Senate mainly relate to institutional matters: the revision and coordination of the Constitution, the adoption of special majority acts, and ordinary acts with an institutional character. The Senate no longer participates in the everyday management of the country, but through the Senate the federated entities now have full co- 
decision power and thus potentially veto power regarding institutional matters.

However, it is doubtful whether the Senate will be able to adequately act as a fullfledged chamber of the federated entities, since the scope of its powers is very limited. In contrast to the German Bundesrat, the Belgian second chamber has limited power to regulate matters with a possible impact on the policy of the federated entities, such as the federal budget (Popelier 2014: 90; Van der Besien 2014: 132). Without new negotiations about a next state reform, the Senate will in practice have almost no substantive work, unless it were to proactively take the role of institutional bridge-builder between the regions and communities as well as think-tank regarding the institutional future of Belgium (Goossens and Cannoot 2013: 7). It should be mentioned that article 42 of the Constitution still stipulates that senators represent the entire nation, even though it was the intention to transform the Senate into a chamber that represents the federated entities.

\subsection{Senate: quo vadis?}

The shortcomings of the Senate reform can be attributed to the absence of a clear vision regarding the future, and the appropriate role, of the Senate (Van der Besien 2014). For instance, most Flemish political parties preferred the abolition of the institution and thus were in favour of the end of bicameralism. Ultimately, the Senate's role could easily be taken over by a special institutional committee within the Chamber of Representatives. Moreover, the interests of the communities and regions are already protected by several other instruments: the presence of language groups in the Chamber of Representatives, the language parity of the federal government, and suspension mechanisms such as the alarm bell procedure and the procedure for conflicts of interest (Popelier 2014). On the other hand, some people advocate the idea of a more influential Senate with full legislative powers for the federated entities at the federal level.

We believe that a well-functioning Senate could be of great value in a federal state. One could opt for a full-fledged chamber of the federated entities, and increase its legislative powers to become similar to those of the German Bundesrat. If the current Senate wants to uphold its raison d'être, it should become a consultation platform where representatives of the federated entities work together on sensitive topics which may lead to disagreements between the communities and regions, and it should reflect on possible future steps in the evolution of the (con)federal Belgian State. 
For now, however, Belgium has an institution whose current value and role are not clear. It is up to the politicians to make a deliberate choice. They should either abolish the Senate and leave its tasks to the Chamber of Representatives, or ensure that the Senate actively resolves tensions between the communities and regions and prepares future institutional steps.

\section{Reform of the Special Finance Act and fiscal autonomy for the regions}

The institutional agreement on the sixth state reform announced a substantial reform regarding the financing of the federated entities. The Special Finance Act of 6 January 2014 substantially expanded the fiscal autonomy of the regions. We will now outline the main principles of the reform.

During the process of Belgium's transformation into a federal state, a complex set of rules had been created to finance the powers of the regions and communities. The third state reform of 1988 led to the adoption of the Special Finance Act, which determined that the financing of the regions and communities mainly stems from allocated parts ('dotations') of federal personal income tax and value-added tax.

Although these dotations are allocated parts of federal taxes, to a certain extent accountability of the regions and communities still remains (Goossens and Van Belle 2012: 1191). As the financial resources are limited, the efficiency level results in more or less financial resources which can be spent for implementing policies. Nevertheless, the recent reform of the Special Finance Act mainly focuses on accountability through fiscal autonomy for the regions. Henceforth, politicians of the regions now have to make choices and justify how they will generate tax revenue in order to accomplish their policy goals. At the time of elections, fiscal autonomy results in democratic accountability. Although the notions 'autonomy' and 'accountability' are quite similar, they ought to be distinguished from each other (Goossens and Van Belle 2012: 1191).

\subsection{Regional fiscal autonomy}

Regional fiscal autonomy in the sixth state reform is expanded by the power for the regions to impose unlimited 'extensive surcharges' (a certain percentage on top of the 
standard tax) in respect of personal income tax. This fiscal autonomy replaces the previous dotation from the revenue of personal income tax. In addition, the regions can now also impose tax increases or decreases, as well as reductions in federal personal income tax concerning matters for which they are competent. The sum of the surcharges, reductions, tax increases and decreases is called the 'regional personal income tax'. Nonetheless, the powers transferred to the regions in the sixth state reform are financed with new dotations instead of increased fiscal autonomy (Goossens and Van Belle 2014: 1).

\subsection{Financing of communal powers}

The powers transferred to the communities in the sixth state reform (e.g. family benefits, care for the elderly, and healthcare) are financed by new dotations. In contrast to the regions, the communities have not acquired any fiscal autonomy, because this might cause problems with regard to the territorial division of powers and the principle of equality in Brussels, as both the Flemish and the French Community are competent on the territory of Brussels. Giving fiscal autonomy to the communities could lead to the establishment of sub-nationalities and an unjustified differential treatment of neighbours in Brussels who might be subjected to different tax rules. As a result, the communities still mainly receive their income from allocated parts (dotations) of the revenue of federal personal income tax and value-added tax.

\subsection{New solidarity mechanism}

Before the sixth state reform, the national solidarity compensation could result in socalled 'perverse effects', such as the 'development trap'. In the latter case a region would receive less dotations in spite of increased tax profit due to economic growth in the region. The sixth state reform has maintained a national solidarity mechanism, but in a more limited way and without perverse effects.

\subsection{Temporary transitional mechanism}

As Wallonia would most likely receive less income in the case of increased regional fiscal autonomy, a (temporary) transitional mechanism was proposed in order to seal the deal during the negotiations on the sixth state reform (Pagano 2013). It was agreed that a region or community could neither be structurally impoverished, nor financially gain or 
lose in the first year that the reform of the Special Finance Act enters into force (Goossens and Van Belle 2014: 1). As from budget year 2015, a transitional amount will be provided for the communities and regions in order to offset the impact of the reform. This amount remains the same in nominal value during the first ten years. During the subsequent ten years, it will decrease linearly (with a gradual decrease of $10 \%$ per year) until it has completely vanished. Hence, Wallonia has been given the time to economically strengthen itself and to increase its income tax revenue.

\section{5. 'Proper funding' of Brussels}

The sixth state reform also provides 'proper funding' of the Belgian capital city (Yernault 2013). There are several reasons why Brussels needs additional funding. Firstly, fiscal autonomy concerning personal income tax as an accountability mechanism is not effective for Brussels. The wages of many employees cannot be subjected to taxation in Brussels, as many of them are commuters who live in other regions. Secondly, Brussels loses significant tax revenue due to the presence of many international and national public institutions which enjoy exemption from property taxation. Finally, the status of Brussels as capital city and headquarters of numerous international institutions entails additional tasks and costs.

Therefore, the additional funding for Brussels will be 461 million EUR by 2015 (Goossens and Van Belle 2012: 1205). One part of this funding is allocated to a specific purpose, for the additional burdens that Brussels bears in comparison to other regions with regard to bilingualism, mobility, training and safety. The other part of the financing is called the 'dead hand' compensation, and is a compensation for the loss of revenue due to the exemption from property tax of numerous buildings. In addition, a structural refinancing is provided for commuters (financed by the other two regions) and international officials (financed by the federal government). After 2015, the additional 'proper funding' of the Brussels-Capital Region will be limited to maximum $0.1 \%$ of the GDP.

\subsection{Climate accountability and contribution to public expenses}

The reform of the Special Finance Act also introduced a climate accountability mechanism for the regions and communities. If a region or community exceeds, or fails to reach, the targets on greenhouse gas emission reduction as defined by the National Climate 
Committee, there will respectively be a financial bonus or malus which will be paid or received by the federal government (Pas 2014: 360).

It is mainly the federal government that pays pensions, even of civil servants of the communities and regions. Traditionally, the regions and communities contributed to these pensions only to a very limited extent based on the Special Act of 5 May 2003. Following the sixth state reform, the financial contribution of the regions and communities in respect of pensions will progressively increase from 2016 onwards. Moreover, the regions and communities will also be required to significantly contribute to the public financing of the State (250 million EUR in 2014, 1.25 billion EUR in 2015 and 2.5 billion EUR from 2016) and the increasing aging cost of the population (a contribution of $0.23 \%$ of GDP by 2030), which will have a substantial impact on their budget.

\section{Transfer of powers in the sixth state reform: Copernican revolution?}

Since 1970, the Belgian Constitution has mentioned the existence of communities and regions. The establishment of these unique federated entities has particular historical origins. Flemish politicians wanted to establish communities to acquire cultural autonomy and protect their language and culture. Walloon, mainly left-wing, politicians on the other hand, pursued economic autonomy via the establishment of regions.

Over time, the communities have acquired legislative powers concerning so-called 'person-related' matters, such as education, culture and assistance to persons. Economic and 'place-related matters', such as spatial planning, public works and agriculture, were transferred to the regions. Other federal countries, such as Germany, Switzerland and the U.S., only have one type of federated state, respectively Länder, cantons and states, based on territory alone. Thus, the unique division of the federated level in Belgium into communities and regions is remarkable and complex.

\subsection{Extensive transfer of powers}

In light of the historical evolution of Belgian federalism, the sixth state reform is undoubtedly a major reform. The whole package of power transfers is extensive (ca. 20 billion euros), especially in comparison with previous state reforms. In addition, for the first time powers regarding social security were transferred to the federated entities, as the 
power concerning family allowances is decentralized from the federal level to the communities. In Brussels, however, the latter power is transferred to the 'Common Community Commission', composed of members of the Brussels-Capital regional parliament. Consequently, the Flemish and French Communities are not competent in Brussels regarding family allowances. The same evolution, which is a break with the past, can be noticed with regard to juvenile criminal law: a transfer of powers to the communities, but in Brussels the (regional) Common Community Commission is competent (Ludmer 2013, Pas 2014: 346).

Moreover, the powers of the communities are expanded in the field of healthcare. In the field of justice, the communities are now competent for the enforcement of penalties, first line legal assistance and juvenile criminal law. On the other hand, certain aspects of the prosecution policy are transferred both to the regions and communities. A large number of powers are also transferred from the federal level to the regions, such as important aspects of labour market policy and road safety. With regard to tourism, the power of the communities is transferred to the regions, notwithstanding a few exceptions.

Due to these power transfers, a paradigm shift has been realized with regard to the distribution of powers, whereby one could argue that most powers are now situated on the level of the federated states. The Flemish budget has now indeed become larger than the federal budget, if one does not take into account the federal power and budget concerning social security. ${ }^{\text {IX }}$

\subsection{Copernican revolution?}

The extensive transfer of powers prompted former Prime Minister Di Rupo to call the sixth state reform a 'Copernican revolution', referring to the renowned statement of former Flemish Minister-President Kris Peeters (Pas 2014: 343). An analysis of the power transfers, however, reveals that the federal level often maintains influence in areas where powers have been transferred to the federated entities. The transfers are characterized by, on the one hand, a high level of fragmentation and, on the other hand, cooperation obligations and increased mutual dependence (Pas 2014: 353).

The current fragmentation is at odds with the intended homogenization of powers, although the feasibility of such homogenization in a federal state has been questioned (Boone 2013: 9, Pas 2014: 350-351). The transfers of powers are very detailed and often 
include exceptions. The complex, highly technical distribution of powers will inevitably lead to conflicts. Moreover, the continuous decentralisation of powers could possibly lead to violations of the principles of EU law regarding the internal market and its economic freedom of movement (Pas 2014: 357-358). In the past, the Court of Justice of the EU already indicated that the distribution of specific powers regarding social security to federated entities might be problematic in light of EU law. ${ }^{\mathrm{x}}$

The sixth state reform also reinforces cooperative federalism in Belgium. In nineteen cases, a cooperation agreement must be reached between the federal level and the federated states. This policy choice of cooperation agreements is quite remarkable. In 2013, the Council of State issued an opinion stating that ten obligatory cooperation agreements, which should have been reached before the sixth state reform, had still not entered into force. ${ }^{\mathrm{XI}}$ Consequently, the Council of State requested the special majority legislator to deliberate on the efficacy of this instrument. Nevertheless, the institutional majority ignored the advice. Through expanding cooperation obligations between the federated entities, Belgium could once again face a joint-decision trap (Pas 2014: 352).

Thus, the sixth state reform undoubtedly adds additional complexity to the Belgian institutional structure and distribution of powers. We believe that it is, therefore, time to question the distinction between communities and regions. A new state structure based on one type of federated state, organised on territorial lines as federal countries like Germany, Switzerland and the U.S., would substantially contribute to a simplification of the labyrinthine Belgian state.

\section{The future of Brussels after the sixth state reform}

The Brussels-Capital Region acquired many new powers in the sixth state reform. Although Flemish politicians repeatedly suggested the combination of a transfer of powers and additional financial means for this region with an internal institutional reform, a simplification has (again) not been achieved. Brussels remains a tangle of institutions, so that a thorough structural reform is still urgent. 


\subsection{The Brussels Region-Community}

Former Flemish Minister-President, Kris Peeters, stated on several occasions that Brussels would never be a full-fledged region, thereby reflecting the vision of several Flemish political parties. ${ }^{\mathrm{XII}}$ However, legally, this statement does not make sense. In fact, Brussels is a full-fledged region and in the sixth state reform it acquired even more powers than the other regions. One could now call Brussels a 'super-region' or 'region-community' (Velaers 2014b: 1023).

As mentioned above, the person-related powers regarding juvenile criminal law and family allowances were transferred to the communities, though in Brussels these passed to the Common Community Commission which is composed of members of the BrusselsCapital regional parliament (Pas 2014: 346). This transfer marked the first time in Belgian institutional history that community powers were allocated to the Brussels-Capital Region. This transfer of powers is remarkable, as the bilingual character of Brussels and the lack of an own autonomous culture are traditionally invoked as arguments against granting community powers to Brussels.

The latter view, which predominated during previous state reforms, has been replaced by a more pragmatic manner of thinking. Although Brussels still caused deep discussions during the sixth state reform negotiations, the attention has shifted towards defending the interests of the region's inhabitants, rather than to traditional institutional antagonisms (Velaers 2014b: 1023). Moreover, the transfer of powers regarding juvenile criminal law and family allowances to the Common Community Commission was considered to be a constitutional necessity. The existence of different family allowance and juvenile criminal law regimes of the French and Flemish Community on the Brussels territory could have led to the establishment of sub-nationalities and a differential treatment, which might be incompatible with the constitutional principle of equality (Dumont and Van Drooghenbroeck 2011).

\subsection{Towards a simplification of the Brussels labyrinth?}

During the negotiations on the sixth state reform, a simplification of the labyrinthine structure of Brussels institutions was proposed. However, the patchwork of municipal, communal and regional institutions has, regrettably, remained intact. 
Brussels has too often been the scene for institutional conflicts and has been the subject of many compromises, so that the structure of Brussels became very complex. The current complex structure originates from the different interests of the federal level, the Flemish and French Communities, the Brussels-Capital Region and the European Union, which each influences Brussels politics. One cannot ignore the special position of Brussels in Belgian federalism as capital of the country, which brings about specific challenges (Velaers 2014b: 985). In addition, 28\% of the population in Brussels does not have the Belgian nationality, which gives rise to challenges with regard to multiculturalism. Brussels is also de facto the capital of the EU and has a strong international character, causing the need for a customized approach.

In conclusion, a simplification of the existing patchwork of Brussels institutions is urgent (Velaers 2014b: 1024). As Brussels faces many socioeconomic challenges due to its status of bilingual and multicultural capital, it is questionable whether it is possible to deal with these challenges without providing a solid solution for the institutional problems. In this regard, it could be necessary for the communities to decrease their influence in Brussels in order to enable a simplification of the institutions and the distribution of powers.

\section{3. 'Frenchification' of Brussels}

Due to the Frenchification starting at the end of the 18th century, there is in practice no real bilingualism in Brussels. In the legal sense the Belgian capital is bilingual, but French has gradually taken the upper hand. Consequently, as part of the deal on the reform of the Brussels judicial district, the Butterfly Agreement, for instance, stipulated that the public prosecutor of the Brussels Public Prosecution Service needed to be French-speaking. However, the Constitutional Court recently annulled this provision. ${ }^{\mathrm{XII}}$ Nevertheless, the annulled provision is a clear indicator of the mind-set resulting from the substantial Frenchification, which is strikingly illustrated by the final report of the Taskforce Brussels in 2012. ${ }^{\mathrm{XIV}}$ The number of Brussels inhabitants whose spoken French is classed as 'well' to 'excellent', remains stable at $95.5 \%$. In contrast, the Dutch-speaking group is limited to $28.2 \%$. Moreover, only $17.2 \%$ of the French-speaking Brussels inhabitants speak Dutch to their Dutch-speaking friends. 
The gap between legal bilingualism and the actual dominance of French is substantial. In fact, the fear of some Flemish inhabitants of Brussels that the influence of the Flemish Community and the use of Dutch will diminish, is justified. The reason why Brussels is still officially bilingual only has historical and political reasons: for centuries, Brussels used to be a Dutch-speaking town and the city still remains the capital of the Flemish Community.

The question rises whether the Flemish-speaking inhabitants of Brussels believe that the ties with the Flemish Community are still desirable and necessary, because Brussels' citizens seem to be increasingly convinced that they form a group which should govern Brussels without interference from the French and Flemish Communities. Cutting the ties between Brussels and the communities thus gradually seems to be entering the Brussels mind-set (Vuye 2012: 246-247). In order to fulfil the increased desire for self-governance in Brussels, a new state structure has been advocated in legal doctrine (Vande Lanotte 2011).

In conclusion, the initial intentions of the sixth state reform regarding a simplification of the Brussels patchwork were laudable, but the execution should have been better and more transparent. Therefore, Brussels will also in the future remain the constitutional laboratory of Belgium.

\section{The future of Belgian federalism}

It should be apparent to the reader by now that Belgium has not yet reached the final stage of its institutional evolution. The implementation of the sixth state reform may therefore be seen as the first step towards the seventh reform of Belgian federalism. The strong Flemish nationalistic movement, the desire for self-governance in Brussels, and the inefficiency of the current federal structure will in all likelihood eventually lead to a seventh state reform with new power transfers to the federated entities (Velaers 2013: 571). However, it is doubtful whether this new state reform will be realised in the next few years. A recent survey (2014) shows a decline of $15.6 \%$ in the desire of Flemish voters to grant more powers to the federated entities, in comparison to the situation before the sixth state reform. The survey shows that currently the majority of Flemings $(57.5 \%)$ are in favour of either the current state structure $(32.8 \%)$ or more powers to the federal level $(13.2 \%)$ or even a unitary state $(11.2 \%)$. The same survey also indicates that employment (43\%), healthcare $(36.9 \%)$ and pensions $(32.4 \%)$ were regarded to be the crucial themes for the 
voters in the 2014 federal elections. Hence, the main focus of the election was not inspired by the need for institutional reform.

The power transfers of the sixth state reform have resulted in a paradigm shift, since the lion's share of powers - excluding social security - is now situated at the level of the federated states. The sixth state reform also thoroughly revised the Special Finance Act, which considerably increased the fiscal autonomy of the regions. Nevertheless, large fixed dotations are still allocated to the communities and regions. Undoubtedly, calls for further raising the level of fiscal autonomy and accountability of the federated entities will be put on the table in the future.

\subsection{Towards a Belgian Union with three or four states?}

The transfer of powers in the sixth state reform resulted in a blurred distinction between the powers of the communities and regions. For the first time, the Brussels Common Community Commission has been granted 'person-related' powers which are traditionally allocated to the communities. This blurred boundary between regions and communities could be the stepping stone to create a new state structure, based on one type of federated entity. Such a transformation might also raise the question of the possibility of 'recentralisation' of powers in certain areas, as the previous state reforms have led to considerable fragmentation of powers. There are no real constitutional taboos in this regard. According to Verdussen (2013: 575), the constitutional framework could be thoroughly rethought, possibly leading to the abolition of the distinction between communities and regions.

Renowned Belgian politician and professor of constitutional law, Johan Vande Lanotte, among others, defends this vision for the future (Vande Lanotte 2011). According to Vande Lanotte, Belgium should become a Union of four federated states, namely Flanders, Wallonia, Brussels and the German-speaking region. Professor Stefan Sottiaux also suggests the creation of the 'United States of Belgium' (Sottiaux 2011). Such an institutional system would be transparent and would enable the federated states to adopt different policies to adequately tackle their own specific problems. For instance, Brussels has typical metropolitan problems, such as migration, transport and employment for poorly educated workers. Challenges requiring a collaborative approach with other states could be dealt with through cooperation agreements. Article 1 of the Constitution, which proclaims 
that Belgium is a federal state consisting of regions and communities, should be altered to reform the Belgian state in the way suggested by Vande Lanotte and Sottiaux. Moreover, we believe that it would be advisable to submit such a significant constitutional reform to the voters for the sake of democratic legitimacy.

Nevertheless, critics of this vision of a Belgian Union with federated states have argued that Brussels would not be able to function without the funding of the other states (Vuye 2012: 252). This is far from being true, as Brussels has a lot of corporation seats. Thus, a decentralisation of corporate taxation would immediately solve the financial problems of Brussels. Moreover, the proximity of Brussels Airport is a huge motor for both local economy and employment.

According to Hendrik Vuye, N-VA fraction leader in the Chamber of Representatives, and constitutional expert, the key word for the further evolution of Brussels - and Belgium in general - is 'asymmetry' (Vuye 2012: 259). According to Vuye, the Walloon and Flemish visions of Brussels do not have to be the same. On the contrary, it will only be when the two communities can constitutionally realize their different visions that Brussels will be able to flourish. In Vuye's vision, Flanders can maintain its institutional connection to Brussels, whilst the French-speakers can develop the French Community Commission (COCOF) into a full-fledged community.

\subsection{Towards a crucial role for the reformed Senate or its abolition?}

The reformed Senate could play a crucial role in a seventh reform of the Belgian state. As described above, the Senate is now a full-fledged chamber of the federated entities, mainly competent for institutional matters. We believe that the senators should be proactive in preparing for future steps in the institutional reform of Belgium by gathering information through expert hearings and debates. The Senate should thus act similarly to the Convention on the Future of Europe, which drafted the notorious EU Constitutional Treaty. It is clear that the current legislative term will be decisive for the role and the future existence of the Senate. If the chamber does not act as a useful platform of (institutional) communication between the regions and communities, it would be better that the Senate be dissolved, and that its function should be integrated within the Chamber of Representatives. 


\footnotetext{
* Jurgen Goossens and Pieter Cannoot are Ph.D. Candidates at Ghent University, Belgium. The authors are founding editors of the Belgian Constitutional Law Blog.

This article has been written after intensive discussions and collaboration with master students of the Advanced Study of Constitutional Law at Ghent University during the fall semester of 2014. In this regard, the authors would like to thank Maarten De Sweemer, Jonas Bel, Laurens Dumoulin, Mukan Heynderickx, Benjamin Magnus, Pauline Verbiest, Célia Nennen, Carl Kyndt, Rutger Goeminne, Eva Van der Meulen, Jana Huyghe, and Pieter Steenhaut. The authors would also like to express their gratitude to Prof. Johan Vande Lanotte and Prof. Stefan Sottiaux for sharing and discussing their vision on the future of Belgium.

I The 'Butterfly Agreement' was named after the bow tie typically worn by former Prime Minister Di Rupo. See http://www.lachambre.be/kvvcr/pdf sections/home/NLdirupo.pdf.

II This quote refers to the legendary remarks made by former Prime Minister Tindemans when he resigned from office.

III The Venice Commission focuses on the improvement of democracy and the rule of law. See http://www.coe.int/en/web/about-us/who-we-are.

IV The full report of the Venice Commission is available at: http://www.venice.coe.int/webforms/documents $/$ default.aspx?pdffile $=$ CDL-AD $\% 282012 \% 29010-\mathrm{e}$.

v Const. Court 26 May 2003, 73/2003, available at: http://www.const-court.be/public/n/2003/2003073n.pdf/.

VI These facilities entitle the French-speaking citizens living in this Flemish area to communicate with the municipal authorities in French.

VII Council of State 20 June 2014, 227.775, available at: http://www.raadvst-consetat.beLarr.php? $\mathrm{nr}=227775 \& \mathrm{l}=\mathrm{nl}$.

VIII Const. Court 30 June 2014, 96/2014, available at: http://www.const-court.be/public/n/2014/2014096n.pdf.

IX See the remarks by Secretary of State for Institutional Reform Servais Verherstraeten, available at: http://www.knack.be/nieuws/belgie/wat-zal-u-voelen-van-de-zesde-staatshervorming-vandaag-nietsmorgen-al-heel-wat-meer/article-opinion-262455.html.

x See Const. Court 21 January 2009, 2009/11, available at: http://www.const-court.be/public/n/2009/2009011n.pdf.

XI Senate, Parliamentary Documents, 5-2232/3, available at: http://www.senate.be/www/?MIval=/publications / viewPub.html\&COLL=S\&LEG $=5 \& N R=2232 \& V O L G N R=3 \& L A N G=n l$.

XII See http://www.nieuwsblad.be/cnt/dmf20110402_008.

XIII Const. Court 30 June 2014, 96/2014, available at: http://www.const-court.be/public/n/2014/2014096n.pdf.

XIV Flemish Community Commission, Task Force Brussel Report, available at: http://brussel.vlaanderen.beLUserFiles/File/TFB eindrapport 20120208.pdf.
}

\section{References}

- Baekeland Christophe and Nelissen Bart, 2014, "De randgemeenten en hun bijzondere regeling na de Zesde Staatshervorming. Kicking the can down the road?”, in Alen André et. al. (eds), Het federale België na de Zesde Staatshervorming, die Keure, Brugge, 255-276.

- Bayenet Benoit and Bourgeois Marc, 2013, "Le financement des entités fédérées en Belgique: quels changements après la sixième réforme de l'Etat ?”, in Sautois Joëlle and Uyttendaele Marc (eds), La sixième réforme de l'Etat (2012-2013). Tournant historique ou soubresaut ordinaire?, Anthemis, Limal, 263-310.

- Boone Ruth, 2013, "In een federale staat bestaan homogene bevoegdheidspakketten eigenlijk niet", Juristenkrant, CCCLXXIX: 8-9. 
- Delgrange Xavier, 2013a, "La déféderalisation de la sécurité sociale, en quête de cohérence au saut dans l'inconnu?", ATP 2013: 1-15.

- Delgrange Xavier, 2013b, "La déféderalisation de la sécurité sociale, un risque pour la société et un defit pour les juges", in Sautois Joëlle and Uyttendaele Marc (eds), La sixième réforme de l'Etat (2012-2013). Tournant historique ou soubresaut ordinaire?, Anthemis, Limal, 411-427.

- Delpérée Francis, 2014, “Le nouveau Sénat. Quelles réalités? Quelles perspectives?”, La Revue Générale, IX-X: 9-11.

- Dumont Hugues and Van Drooghenbroeck Sébastien, 2011, “L'interdiction des sous-nationalités à Bruxelles", ATP 2011: 201-226.

- $\quad$ Feyt Anne and Vandernacht Pascale, 2013, "La réforme du Sénat, un tableau inachevé...”, in Sautois Joëlle and Uyttendaele Marc (eds), La sixième réforme de l'Etat (2012-2013). Tournant historique ou soubresaut ordinaire?, Anthemis, Limal, 81-101.

- Fornoville Claire, 2014, "De Vlinder-Senaat", in Velaers Jan et. al. (eds), De Zesde Staatshervorming. Instellingen, bevoegdheden en middelen, Intersentia, Antwerpen, 17-52.

- Goossens Jurgen and Cannoot Pieter, 2013, “Een nieuwe Senaat: een maat voor niets?”, Juristenkrant, CCLXXVII: 6-7.

- Goossens Jurgen and Van Belle Sibylle, 2012, "Institutioneel akkoord over de Bijzondere Financieringswet ontsluierd”, Rechtskundig Weekblad, XXVII: 1190-1208.

- Goossens Jurgen and Van Belle Sibylle, 2014, "Zesde staatshervorming: welke fiscale bevoegdheden voor de Gewesten?”, Fiscoloog, MCCCLXXIII: 1-6.

- Gosselin, Frédéric, 2013, "La réforme de l'arrondissement judiciaire de Bruxelles”, in Sautois Joëlle and Uyttendaele Marc (eds), La sixième réforme de l'Etat (2012-2013). Tournant historique ou soubresaut ordinaire?, Anthemis, Limal, 375-396.

- Ludmer Julie, 2013, "Les nouvelles compétences des Communautés et de la Commission communautaire commune dans les matières personnalisables. Et si l'accord papillon leur donnait des ailes", in Sautois Joëlle and Uyttendaele Marc (eds), La sixième réforme de l'état (2012-2013). Tournant historique ou soubresaut ordinaire?, Anthemis, Limal, 397-410.

- Mnookin Robert and Verbeke Alain, 2009, "Persistent Nonviolent conflict with no reconciliation: the Flemish and Walloons in Belgium", Law and Contemporary Problems, LXXII: 151-186.

- Mollin July, 2013, "De Grondwet, een vodje papier”, Juristenkrant, CCXLVI: 10-11.

- $\quad$ Muylle Koen, 2014, "De hervorming van de Senaat en de samenvallende verkiezingen: een processie van Echternach naar de federale (model)staat?", in Alen André et. al. (eds), Het federale België na de Zesde Staatshervorming, die Keure, Brugge, 103-124.

- $\quad$ Pagano Giuseppe, 2013, “La sixième réforme de l'Etat: autonomie fiscale vs solidarité, le cas de la Région wallonne", in Sautois Joëlle and Uyttendaele Marc (eds), La sixième réforme de l'état (2012-2013). Tournant historique ou soubresaut ordinaire?, Anthemis, Limal, 2013, 359-371.

- Pas Wouter, 2011, "Federalisme met gemeenschappen en gewesten: een tussenstand van moeilijkheden, mogelijkheden en voorstellen”, TBP: 486-501.

- $\quad$ Pas Wouter, 2014, "Algemene beschouwingen over de bevoegdheidsverdeling in het kader van de zesde staatshervorming" in Alen André et. al. (eds), Het federale België na de zesde staatshervorming, die Keure, Brugge, 342-371.

- Peeters Patrick, 2007, "De Senaat opnieuw ter discussie", in Peeters Bruno and Velaers Jan (eds), De Grondwet in groothoekperspectief, Intersentia, Antwerpen, 2007, 231-238.

- $\quad$ Peeters Patrick, 2013, “De 'overgangsbepaling' van artikel 195 van de Grondwet: een noodzakelijke voorwaarde voor de uitvoering van de zesde staatshervorming”, TBP: 379-388. 
- Peeters Patrick and Mosselmans Jens, 2009, "Belgium, The Brussels-Halle-Vilvoorde Question: A Linguistic Trap", European Public Law, XV(1): 5-15.

- Peiffer Quentin, 2014, “La sixième réforme de l'état sous l'angle des compétences culturelles et du tourisme à Bruxelles", ATP 2014: 14-33.

- Popelier Patricia, 2012, "De truc met artikel 195: een lapje voor het bloeden met de zegen van Venetië", CDPK: 421-443.

- Popelier Patricia, 2014, "Het kaduke masker van de Senaat: tussen deelstaatfederalisme en multinationaal confederalisme", in Velaers Jan et. al. (eds), De Zesde Staatshervorming. Instellingen, bevoegdheden en middelen, Intersentia, Antwerpen 53-90.

- $\quad$ Remiche Adélaïde and Van Den Eynde Laura, 2013, "La nouvelle procédure de nomination des bourgmestres des six communes à facilités de la périphérie bruxelloise", in Sautois Joëlle and Uyttendaele Marc (eds), La sixième réforme de l'Etat (2012-2013). Tournant historique ou soubresaut ordinaire?, Anthemis, Limal, 227-259.

- Rezsohazy André and Van Der Hulst Marc, 2014, "De verdeling van de wetgevende bevoegdheid tussen Kamer en Senaat na de zesde staatshervorming”, TVW, 2014-I: 40-57.

- Rigodanzo Vanessa and Slautsky Emmanuel, 2013, "La scission de la circonscription électorale de Bruxelles-Hal-Vilvorde", in Sautois Joëlle and Uyttendaele Marc (eds), La sixième réforme de l'Etat (2012-2013). Tournant historique ou soubresaut ordinaire?, Anthemis, Limal, 2013, 145-191.

- $\quad$ Sottiaux Stefan, 2011, De Verenigde Staten van België. Reflecties over de toekomst van het grondwettelijk recht in de gelaagde rechtsorde, Kluwer, Mechelen.

- Vande Lanotte Johan, 2011, "Vlugschrift: De Belgische Unie bestaat uit vier deelstaten", 1-24, available at http://www.s-p-a.be/media/uploads/pdf/belgische unie.pdf.

- Vandenbruwaene Werner, 2014, "Het gerechtelijk arrondisement Brussel”, in Velaers Jan et. al. (eds), De zesde staatshervorming: instellingen, bevoegdheden en middelen, Intersentia, Antwerpen, 203-214.

- Van Der Biesen Gert, 2014, "De nieuwe wetgevingsprocedure", in A. Alen et. al. (eds), Het federale België na de Zesde Staatshervorming, die Keure, Brugge, 125-142.

- Vandernoot Pierre, 2013, “La révision de l'article 195 de la Constitution du 29 mars 2012: 'Ceci (n')est (pas) une révision"', in Sautois Joëlle and Uyttendaele Marc (eds), La sixième réforme de l'Etat (2012-2013). Tournant historique ou soubresaut ordinaire?, Anthemis, Limal, 13-80.

- Vanlerberghe Beatrix, 2014, "Het gerechtelijk arrondissement Brussel”, in Alen André et. al. (eds), Het federale België na de Zesde Staatshervorming, die Keure, Brugge, 191-212.

- Van Nieuwenhove Jeroen, 2012, “De nieuwe 'overgangsbepaling' bij artikel 195 van de Grondwet. Een herbruikbare tijdelijke afwijking van de herzieningsprocedure?”, TVW: 156-172.

- Van Nieuwenhove Jeroen, 2013, "De splitsing van de kieskring Brussel-Halle-Vilvoorde: over vijf minuten die tien jaar werden”, TBP: 389-416.

- Velaers Jan, 2013, “Quel avenir pour la Belgique”, in Sautois Joëlle and Uyttendaele Marc (eds), La sixième réforme de l'Etat (2012-2013). Tournant historique ou soubresaut ordinaire?, Anthemis, Limal, 567-571.

- Velaers Jan, 2014a, "De splitsing van de kieskring BHV en de bijzondere regelingen voor de randgemeenten: de bevoegdheid van de algemene vergadering van de Raad van State, de benoeming van de burgemeesters en de stand still”, in Velaers Jan et. al. (eds), De zesde staatshervorming: instellingen, bevoegdheden en middelen, Intersentia, Antwerpen, 151-201.

- Velaers Jan, 2014b, "Brussel in de zesde staatshervorming", in Velaers Jan et. al. (eds), De zesde staatshervorming: instellingen, bevoegdheden en middelen, Intersentia, Antwerpen, 965-1025.

- Verdussen Marc, 2013, "La Belgique appartient-elle à l’avenir ou au passé ? “ in Sautois Joëlle and Uyttendaele Marc (eds), La sixième réforme de l'Etat (2012-2013). Tournant bistorique on soubresaut ordinaire?, Anthemis, Limal, 573-581. 
- Vuye Hendrik, 2012, "Brussel: enkele modellen en hun(on)mogelijke gevolgen”, CDPK: 244-262.

- Vuye Hendrik and Clemer Guy, 2013, De zesde staatshervorming (eerste fase): Het BHV-akkoord of de ultieme vergrendeling, Intersentia, Antwerpen.

- Yernault Dimitri, 2013, "Le refinancement de Bruxelles : “juste “, “correct” ou... ?”, in Sautois Joëlle and Uyttendaele Marc (eds), La sixième réforme de l'Etat (2012-2013). Tournant historique ou soubresaut ordinaire?, Anthemis, Limal, 311-358. 